\title{
Water history and transdisciplinarity: a South African perspective ${ }^{1}$
}

\author{
JWN TEMPELHOFF
}

\begin{abstract}
In the article attention is given to recent developments in the field of water history at North-West University in South Africa, where transdisciplinary research strategies have been incorporated into research programmes on contemporary problems experienced in the country's water sector. The initial focus on water history gradually shifts to water studies and how interdisciplinary research and the exponential growth of scientific knowledge has opened up space for the emergence of transdisciplinary research. There is a discussion on the research undertaken by members of the Research Niche Area for the Cultural Dynamics of Water (CuDyWat) at the university and an outline of some of the group's completed research reports. The potential value of current research is also examined.
\end{abstract}

Keywords: water studies; South Africa; water sector; water history; transdisciplinary research.

Disciplines: History, water studies, transdisciplinarity.

\section{Introduction}

Since South Africa's transition to a multiracial democracy in 1994 the country has been on a remarkable development trajectory. The recent history of the country's water sector tells the story of a society grappling with challenges of rapid population growth, urbanisation, transformation of governance structures and plans to deal with other critical problems that have arisen. Two examples explain the point.

1. Based on a paper presented at the seventh global conference of the International Water History Association, "Talking Water History on the African Veld", Mopani Rest Camp, Kruger National Park, South Africa, 5-7 July 2011. A special word of thanks to Dr. Bridget Theron, who not only edited the text, but also provided some valuable suggestions on the article.

2. Prof. Johann Tempelhoff is at the helm of the Research Niche for the Cultural Dynamics of Water $(\mathrm{CuDyWat})$ in the School of Basic Sciences at North-West University (Vaal). 
On 13 April 2011, Mr Andries Tatane (33) was killed as a result of police action to control a service delivery protest march in the town of Ficksburg, in the eastern Free State Province. ${ }^{3}$ Discontent with existing municipal service delivery - of which water services form an important part - has featured prominently in South Africa's contemporary historical consciousness since 2004. It is also a consciousness that reaches deeper into the South African psyche. Almost immediately after the Ficksburg protest, the death of Tatane was compared to that of the 12-year old martyr figure, Hector Pieterson (1964-1976), ${ }^{4}$ who died when hit by a stray bullet fired by police at the time of the Soweto uprisings in $1976 .{ }^{5}$

The second example dates back to 2010, when residents of the Witwatersrand region of Gauteng Province, the economic hub of South Africa, were made aware of the imminent crisis of toxic acid mine drainage water decanting from worked-out mine shafts in what used to be the premier goldfields of South Africa. ${ }^{6}$ Experts warned that the contaminated groundwater, rising at a rate of about $500 \mathrm{~mm}$ per day, could reach the surface in downtown Johannesburg in vast quantities within the next year. ${ }^{7}$

The historian's ability to reflect upon and interpret society's temporalities ${ }^{8}$ is crucial for the understanding of water-related problems in South Africa. Although municipal service delivery and the crisis of acid mine drainage appear to have a strong contemporary inclination, both are deeply rooted in South African history. Municipal governance crises can be traced back to underdevelopment in the apartheid era, while the acid mine drainage is representative of the consequences of South Africa mining history that boosted the economic development.

In view of the fact that the country is currently on a major new development trajectory it is not always possible for the practising historian to focus exclusively (and more comfortably) on an arcane past. The present, pressing circumstances demand that the historian engage directly with what is transpiring in contemporary South African society. This is not to deny the distinct need for a sense of historical consciousness in dealing with contemporary water problems. The opposite is true; a knowledge and understanding of the past is vital in the search for solutions in the present and planning for the future. Although it is widely acknowledged that the current problems in the water sector had their origin in the era of the former government, there are also indications that many water-related problems can be ascribed to the manner in which post-1994 authorities have chosen to deal with the

3. TS Maluleke, "Meet Andries. He died yesterday" in Mail \& Guardian: thought leader, 2011.0415 at http://www.thoughtleader.co.za/tinyikosammaluleke/2011/04/15/meet-andries-he-died-yesterday/ (Accessed 2011.10.21).

4. Anon., "Hector Pieterson" in South African History Online at http://www.sahistory.org.za/pages/people/bios/pieterson-h.htm (Accessed 2011.04.29).

5. B-A Mngxitama, "Tatane's death underlines need for government to deliver" in Sowetan Live, 2011.04.19 at http://www.sowetanlive.co.za/columnists/2011/04/19/tatane-s-death-underlines-needfor-government-to-deliver (Accessed 20911.1021).

6. Inter-ministerial Committee on Acid Mine Drainage (I-MCAMD), "Mine water management in the Witwatersrand gold fields with special emphasis on acid mine drainage" (December 2010).

7. L van Vuuren, "Red letter year for authorities to prevent mine-water catastrophe: acid mine drainage" in Water Wheel, 10(1), January/February 2011, pp. 12-14.

8. WH Sewell, Logics of history: social theory and social transformation (University of Chicago Press, Chicago, 2005), p. 6. 
challenges of rapid development. ${ }^{9}$ The contemporary history of South Africa is currently the domain of sociologists, development studies specialists and political scientists. It is perhaps high time that historians begin to reflect on the times in which we are living.

South Africa's contemporary water history is a particularly fertile field of exploration. There is an abundance of source material on which to base some historical studies on water that are both interesting and highly relevant. Not only do the media frequently report on water matters; an abundance of documentation is also accessible on the Internet and in the electronic archives of government departments. Thanks to government's compliance with demands for transparency and the right to access of information, there is a veritable cornfield of source material waiting for the historian to harvest. ${ }^{10}$ The contemporary water history of South Africa arguably proves to be just as exciting as national and international political historiography. Thanks to global sector linkages, the discourse on contemporary water history has transcended national boundaries. Perhaps the greatest benefit of working in the water sector is that historical research can make a significant contribution to our understanding of complex problems that currently plague the provision of water to communities countrywide.

\section{Outline}

In the discussion that follows, attention is given to the growth of water history in recent times; the concept of water studies and how history fits into this; water studies; interdisciplinarity and history; the emergence of transdisciplinarity; and water history at North-West University. Specific attention will be given to the Research Niche for the Cultural Dynamics of Water (CuDyWat) and how research leaders and students conduct their research and work towards securing sufficient stakeholder participation in the generation of valuable water knowledge that makes a meaningful contribution towards solving some of the problems currently experienced in the country's water sector. Broadly speaking, the discussion is aimed at how the work was carried out; how some of the challenges encountered were addressed; and at shedding some light on what has been achieved thus far.

\section{The growth of water history}

Since the establishment of the International Water History Association (IWHA) in the 1990s, the discipline of water history has made substantial progress. The society's journal Water History was founded in 2009 and has subsequently showcased contemporary water

9. JWN Tempelhoff, "Local service delivery problems and trends in South Africa's water governance (1994-2010)". Currently submitted for peer review and possible publication.

10. Note: This article was written in the first half of 2011. On 21 November 2011 a majority of parliamentarians in South Africa's legislative Assembly voted in favour of the Protection of State information Bill that had been under discussion for a considerable period of time. See I-Net Bridge, "ANC uses voting muscle to pass secrecy law" in Business Report, 2011.11.22 at http://www.iol.co.za/business/business-news/anc-uses-voting-muscle-to-pass-secrecy-law-1.1184080

Accessed 2011.12.01). Judging from the public response and expert legal opinions there are indications that the state may clamp down on the free access to information. The bill still has to be signed by the state president. Also, it appears as if there will be considerable opposition in various sectors of civil society $t$ oppose the proposed legislation. 
research. Historians in many parts of the world have made contributions in a field that appears to be growing in popularity. Since 2009 the IWHA has been an active partner in global initiatives by the International Consortium of Environmental History Organisations (ICEHO) to foster and promote the sharing of information amongst history organisations with an environmental inclination. The IWHA has also actively supported the International Water Association's Specialist Group on Water and Wastewater Technologies in Ancient Civilisations. At UNESCO's Institute for Hydrological Education in Delft (UNESCOIHE), postgraduate students in water studies have for the past four years followed a course on the History of World Civilisations and Water Management. Needless to say all these ventures have contributed substantially to promoting the cause of water history.

A notable feature of the field is its diverse foci. Currently art historians, political scientists, philosophers, archaeologists, anthropologists, sociologists and geographers, as well as a good smattering of engineers and geohydrologists, are active participants in the production of research reports.

It is apparent that the discipline is alive and well and there are indications of new approaches to certain water issues. Internationally the output is also increasing. Some of the outstanding publications of recent years include the monumental project under the leadership of Norway's Terje Tvedt that has entered a second phase since 2006 when the first of three substantial volumes of water history were published. ${ }^{11}$ The fields of focus are broad. In 2007, Juuti, Katko and Vuorinen collaborated to edit an international environmental history of water. ${ }^{12}$ Another informative work, Cech's monograph, Principles of water resources: bistory, development, management and policy, ${ }^{13}$ is mainly intended for college students and has enjoyed a consistent readership since the publication of the first edition in 2003. Recently, Solomon's global history of water has made inroads into the market of popular historiography ${ }^{14}$ and Fekri Hassan's initiative on the history of world civilisation and water, in conjunction with UNESCO-IHP, is due to be published in the near future. In 2011, a philosophical and integrated theoretical outline of his water history vision appeared and is proving to be a valuable contribution for advanced students of water history. ${ }^{15}$

\section{Water studies}

The field of water studies is an umbrella for a number of disciplines in the natural, socioeconomic and human sciences that contribute to our developing knowledge of water. The extraordinary drought conditions experienced in the 1960s sparked the need in South Africa

11. T Tvedt, E Jakobson, R Coopey and T Oestigaard (eds.), A history of water Vols 1-3 (IB Taurus \& Co, London, 2006).

12. PS Juuti, TS Katko and HS Vuorinen (eds), Environmental history of water (IWA Publishing, London, 2007).

13. TV Cech, Principles of water resources: history, development, management and policy (Third edition, Wiley \& Sons Inc., Danvers MA, 2009).

14. S Solomon, Water: the epic struggle for wealth, power and civilization (Harper, New York, 2010).

15. F Hassan, "Water History for our times" in IHP Essays on water history, Volume 2 (UNESCO International Hydrological Program, Paris, 2011). 
for a comprehensive understanding of water-related issues. ${ }^{16}$ This in turn led to the establishment of the Water Research Commission in 1971, which, along with the Council for Scientific and Industrial Research (CSIR), and the National Research Foundation (NRF), have collaborated with the country's tertiary educational and research institutions to expand the range and complexity of the field.

A notable feature of water studies in the twenty-first century is the marked shifts that have taken place. There has been significant growth in support for the opinion that water should be viewed in global paradigms; ${ }^{17}$ previously, it was a field of research, which contemplated water from the perspectives of quality and scarcity. By the 1970s a growing wave of environmental awareness, especially in the United States and later also in Europe, made a marked impact on trends in research and development. The concept of sustainable development, outlined in the Brundtland Report (1987), and the consensus reached at the Rio Earth Summit of 1992 on the growing scarcity of water, ${ }^{18}$ found expression in a number of changes. ${ }^{19}$ Of particular importance was the evolution of integrated water resource management (IWRM) ${ }^{20}$ - a holistic strategy for the better understanding of water governance. Specialists in water studies are currently acutely aware that operators in the water sector require knowledge that is grounded on the ability to determine basic human and ecosystem needs; the impact of climate change; and a wide variety of issues in the fields of management and planning. ${ }^{21}$

\section{History and water studies}

Contemplated from the perspective of knowledge formation, history is a discipline that can be categorised as either a social or human science. ${ }^{22}$ The understanding is that if history is classified as a social science, its theoretical and methodological tenets are rooted in disciplines

16. L van Vuuren, "Water Research Commission - celebrating 40 years of research excellence" in Water Wheel, 10(5), Supplement to September/October 2011, pp. 6-10.

17. A Kirby and V Spedding, The boldness of small steps: ten years of the Global Water Partnership, (Elanders AB for Global Water Partnership, Mölnlycke, 2006), pp. 1-3; SC Anisfield, Water resources (Island Press, Washington, Covelo and London, 2010), pp. 6-10; Also see Anon., "History" in Global Water Partnership at http://www.gwp.org/en/About-GWP/History/ (Accessed 2011.05.10).

18. For the background and guidelines for the understanding of the problem, see "The Dublin Statement on Water and Sustainable Development" at http://www.wmo.int/pages/prog/hwrp/documents/english/icwedece.html (Accessed 201109.29).

19. Anon., "UN Conference on environment and development (1992)" at http://www.un.org/geninfo/bp/enviro.html (Accessed 2011.09.29).

20. P Jeffrey and M Gearey, "Integrated water resources management: lost on the road from ambition to realization?" in Water Science and Technology, 53(1), 2006, pp. 1-8.

21. PH Gleick and DJ Cuff, "Water", in The Oxford Companion to Global Change. Ed. David Cuff and Andrew Goudie (Oxford University Press, 2009. Oxford Reference Online. Oxford University $\begin{array}{lllll}\text { Press. University of North } & \text { West }\end{array}$ 2011 http://www.oxfordreference.com/views/ENTRY.html?subview=Main\&entry=t265.e239

22. P Weingart, "A short history of knowledge formations" in R Frodeman, J Thompson Klein, C Mitcham and J Britt Holbrook (eds.), The Oxford handbook of interdisciplinarity (Oxford University Press, Oxford, 2010), pp. 3-14. 
with a nomothetic or deterministic inclination, such as sociology, psychology and economics. Since the nineteenth century these disciplines have all been influenced by the natural sciences. A notable feature of this approach to history is its ability to contribute to theory formation and the development of methodology. If history is categorised as a human science this implies that the discipline functions in the ambit of subjects in which the study of language and texts, and the meaning of words (philology) are studied. ${ }^{23}$ It then takes on an ideographic character which means that humanistic reasoning strategies, such as for example hermeneutics, feature prominently in this approach to history. ${ }^{24}$ This approach is redolent with uncertainties and inconsistencies and can hardly be compared to the search for accuracy or the precision of universal logic that the nomothetic approach aspires to. However, the ability to identify a unique and singular line of development may well provide important clues to solving specific scientific problems.

Until the 1970s, history as discipline in the field of water studies was notable for its historiographical focus on themes such as the commemoration of technological heritage; biographical studies of leading figures in the water sector; and a growing interest in rediscovering technologies of antiquity that were useful in the fields of civil engineering and hydrology. By the 1980s, historians in the United States were beginning to ask different questions. They began moving beyond the mere history of technology; instead they explored aspects of politics, social history and intellectual thinking that shaped the way in which we perceive infrastructural goods and services, such as water, sanitation, electricity and communications. ${ }^{25}$ Nature, biological evolution and an acute awareness of humankind's role on earth, reached a point by the beginning of the twenty-first century, where historians and natural scientists were working in the direction of the re-periodisation of the earth's natural history to make provision for what has been labelled the Anthropocene. ${ }^{26}$ Historians, along with scientists in almost all fields of endeavour, have become more aware of the environment. $^{27}$

23. MC Howell and W Prevenier, From reliable sources: an introduction to historical methods (Cornell University Press, New York, 2001), pp. 99-104.

24. For the evolutionary lines in this development, see $G$ Hirsch Hadorn, S Biber-Klemm, W Grossenbacher-Mansuy, H Hoffman-Riem, D Joye, C Pohl, U Wiesmann and E Zemp, "The emergence of transdisciplinarity as a form of research" in G Hirsch Hadorn, H Hoffmann-Riem, S Biber-Klemm, W Grossenbacher-Mansuy, D Joyce, C Pohl, U Wiesmann and E Zemp (eds), Handbook of transdisciplinary research (Springer Science and Business Media B.V., Dordrecht, 2008), pp. 21-22.

25. See for example, JW Konvitz, MH Rose and JA Tarr, "Technology and the city" in Technology and Culture, 31(2), April 1990, pp. 284-294.

26. C Sagan, OB Toon and JB Pollock, "Anthropogenic albedo changes and the earth's climate" in Science, 206(4425), 1979.12.21, pp. 13630-1368; PJ Crutzen, and EF Stoermer, The "Anthropocene" in IGBP Newsletter, 41, pp. 17-18; PJ Crutzen, "Geology of mankind - The Anthropocene" in Nature, 415, 2002. p. 23; D Chakrabarty, "The climate of history: four theses" in Critical Inquiry, 35(2), Winter 2009, pp. 197-222.

27. JK Stine, JA Tarr, "At the intersection of histories: technology and the environment" in Technology $\&$ " Culture, 39(4) October 1998, pp. 601-640; JH McNeill, Something new under the sun: an environmental history of the twentieth century world (Penguin, London, 2000); J Radkau, Natur und Macht: eine Weltgeschichte der Umwelt, (Second edition, CH Beck, München, 2002); JR McNeill, "Observations on the nature and culture of environmental history" in History and Theory, Theme issue, 42(4), December 2003, pp. 5-43; W Beinart, "African history and environmental history" in African Affairs, 99, 2000, pp.

Td, 7(1), Julie 2011, pp. 316- 336. 


\section{Water studies, interdisciplinarity and transdisciplinarity}

The objective in this section is to establish a linkage between water studies and transdisciplinarity. To do that we need to go back to the final quarter of the twentieth century. In the 1970 s water studies initially appeared to have a strong interdisciplinary inclination. It suited the need for a specific type of knowledge creation because interdisciplinarity is intent on transferring the methods of one discipline to another. Later, water studies acquired a more multidisciplinary focus, of which the most notable feature was that practitioners in the fields identified a problem and used several disciplines to solve it. ${ }^{28}$ True to the nature of knowledge creation in the natural sciences, the objective was to solve problems instead of merely operating in disciplinary silos. ${ }^{29}$ This approach made it possible for significant cross-boundary interaction, particularly in the natural sciences. There were also strong indications of collaboration with the social sciences. Annales-type historiography tended to fit in well with the natural sciences and interdisciplinarity. ${ }^{30}$ In the United States interdisciplinary history made significant headway at the Massachusetts Institute of Technology, with the publication of the Journal of Interdisciplinary History in 1969 under the guidance of Robert I Rotberg and Theodor K Rabb. ${ }^{31}$ History was clearly capable of interacting in the broader field of water studies. At the time the National Science Foundation in the US actively promoted a programme entitled Interdisciplinary Research Relevant to Problems of Our Society (IRROPS). This gradually shifted in accent to concentrate specifically on problem-solving research. ${ }^{32}$

In Europe in the early 1970s, influential academics such as the Austrian astrophysicist Erich Jantsch (1929-1980), ${ }^{33}$ and the Swiss scholar, Jean Piaget (1896-1980), ${ }^{34}$ made statements on a new approach to knowledge generation. They were in favour of transdisciplinarity in an era when the general academic environment was not at the forefront of knowledge creation and education in a rapidly changing world. Transdisciplinarity ${ }^{35}$ was considered to be far more

269-302; W Beinart, The rise of conservation in South Africa: settlers, livestock, and the environment 17701950 (Oxford University Press, Oxford,2003).

28. B Nicolescu, "A new vision of the world - transdisciplinarity" in Anon., The design and delivery of interand pluri-disciplinary research: proceedings from MUSCIPOLI Workshop Two (Danish Institute for Studies in Research and research Policy, 2002/7, Ahrus, 2002), pp. 109-110.

29. R Post, "Disciplinarity" in Critical Inquiry, 35(4), Summer 2009, p. 755.

30. For the manner in which the Annales School worked at transcending disciplines, see F Braudel, On bistory (The University of Chicago Press, Chicago, 1980).

31. Anon., "The Journal of Interdisciplinary History" in MIT Press Journals at http://www.mitpressjournals.org/page/about/more/jih (Accessed 2011.05.05).

32. JT Klein, Interdisciplinarity: history, theory \& practice (Wayne State University, Detroit, 1990), p. 35.

33. E Jantsch, "Inter- and transdisciplinary university: a systems approach to education and innovation" in Policy Sciences, 1(4), Winter 1970, pp. 403-428; Kykook E Jantsch, "Inter- and transdisciplinary university: a systems approach to education and innovation" in Higher Education, 1(1), February 1972, pp. 7-37.

34. JT Klein, Interdisciplinarity: history, theory E practice (Wayne State University, Detroit, 1990), p. 29.

35. Although transdisciplinarity as term has been in circulation for a considerable period of time there is currently a tendency to make specific use of the term transdisciplinary research. It suggests a greater accent on method in the execution of research. See B Nicolescu (ed.) Transdisciplinarity: theory and 
comprehensive in scope than conventional inter- and multidisciplinary approaches. For a start there was a search for overarching synthesis similar to that of Marxism, behaviourism and exchange theory, structuralism and social phenomenology. These theoretical approaches literally formed hybrid spaces of thinking beyond singular disciplines. ${ }^{36}$ Of importance was that proponents of transdisciplinarity described it as a system that tended to transcend a particular range of disciplinary thinking. For example they argued that order, as it existed, was part of an organisational system that contained serious limitations, ${ }^{37}$ because:

\section{A totally determined universe is a universe where nothing new can transpire and where} the observing human mind ... (can) not be introduced. ${ }^{38}$

Transdisciplinarity was above all a response to the socioeconomic changes that were taking place in Western Europe and the United States. ${ }^{39}$ According to Nowotny, at the beginning of the twentieth century the social sciences were faced with the need to develop a comprehensive framework in which to place the overarching problems of the integration of the masses into the processes of modernisation, industrialisation and urbanisation. This process continued at the political level where the concept of citizenship became more inclusive, which also implied that social groups (with their specific rights and needs) could be incorporated, depite potential class issues that would formerly have excluded people from certain forms of intellectual knowledge. In the economic sphere industrial workers were integrated into the system of mass production; this in turn directly drew them into the process of becoming consumers. Cultural integration occurred through education, which homogenised the ethnic and national identity of people resident within the boundaries of the national state. ${ }^{40}$ Countries of the colonial south were noticeably absent from these developments. It evidently had an influence on the manner in which scientific thinking evolved in these regions. ${ }^{41}$ After 1945, a new post-World War II generation of 'baby boomers' demanded education and knowledge in a formal system of education. Working class youths in Western Europe, for example, grew intolerant of education that tended to be exclusionary at secondary and tertiary

practice (Hampton Press, New York, 2008); C Pohl, "From transdisciplinarity to transdisciplinary research" in Transdisciplinary Journal of Engineering EO Science 1(1), December, 2010, pp. 74-83.

36. JT Klein, Interdisciplinarity: history, theory \& practice (Wayne State University, Detroit, 1990), pp. 6566.

37. R Hoggart, "Humanistic studies and mass culture" in Daedalus, 99(2), Theory in Humanistic Studies, Spring 1970, pp. 451-472.

38. E Morin and F Coppay, "Beyond determinism: the dialogue of order and disorder" in Substance, 12(3), 1983, Issue 40: Determinism, p. 28.

39. G Hirsch Hadorn, S Biber-Klemm, W Grossenbacher-Mansuy, H Hoffman-Riem, D Joye, C Pohl, U Wiesmann and E Zemp, "The emergence of transdisciplinarity as a form of research" in G Hirsch Hadorn, H Hoffmann-Riem, S Biber-Klemm, W Grossenbacher-Mansuy, D Joyce, C Pohl, U Wiesmann and E Zemp (eds), Handbook of transdisciplinary research (Springer Science and Business Media B.V., Dordrecht, 2008), pp. 19-39.

40 . H Nowotny, "Re-thinking science: from reliable to socially robust knowledge" in H Nowotny and M Weiss (eds), Jabrbuch 2000 des Collegium Helveticum der ETH Zürich, (Zurich, 2000), p. 236.

41. G Hirsch Hadorn, S Biber-Klemm, W Grossenbacher-Mansuy, H Hoffman-Riem, D Joye, C Pohl, and U Wiesmann and E Zemp, "The emergence of transdisciplinarity as a form of research" in G Hirsch Hadorn, H Hoffmann-Riem, S Biber-Klemm, W Grossenbacher-Mansuy, D Joyce, C Pohl, U Wiesmann and E Zemp (eds), Handbook of transdisciplinary research, (Springer Science and Business Media B.V., Dordrecht, 2008), pp. 19-39. 
level and demanded greater access to tertiary education. At the same time technological innovation appeared to be taking place much more rapidly outside academia than within its previously hallowed halls. In the face of significant technological changes, especially in the engineering sciences and information technology, the need for the incorporation of more areas of study increased significantly. In the humanities and social sciences there was a growing tendency to embrace postmodernist thinking. It tended to look at science and scientific thinking in the field of grand theory in a different manner. ${ }^{42}$

By the 1990s the global political landscape had changed significantly. In the post-Cold War era the states of the world were no longer focused on security in an ideologically divided world. Instead, the focus shifted to competing on other levels and improving the lives of the state's own citizens. Economic growth and development, especially in the developing countries became the foremost preoccupation of governments. ${ }^{43}$ The formal affirmation of this way of thinking was the publication in 1994 of The new production of knowledge, by Gibbons, Limoges, Nowotny, Schwartzman, Scott and Trow. ${ }^{44}$ The message was that a new research dispensation was presenting itself with a greater accent on social dispersion and participation in the research process. The features of transdisciplinarity appealed to potential practitioners because it appeared to:

- Have the capability of offering distinct evolving frameworks of problem solving;

- Make marked inroads in the process of (non-monodisciplinary) knowledge;

- Contribute to the diffusion of knowledge to stakeholder groups, instead of institutional channels; and

- Offer a dynamic form of problem solving 'on the move'. ${ }^{45}$

It was all about introducing Mode 2-knowledge. Whereas Mode 1-knowledge was associated with traditional, formal systems of creating knowledge in a classical, scholarly fashion, Mode 2-knowledge came across as part of a new, innovative generation of learning and research knowledge creation, associated with a new type of learning that was not confined to academia. It was more comprehensive and intent on dealing with the problems of the present and finding solutions. ${ }^{46}$

The appeal of transdisciplinarity was that it seemed to address the needs of managers of educational and research institutions, academics who had been working at problem-solving, as well as research funders who wanted to get to the heart of the issue when they sponsored knowledge creation. This fresh approach to thinking slowly began to make its mark. However, its acceptance was gradual. In 1997, Abelson, in an editorial on higher education in

42. JT Klein, Interdisciplinarity: history, theory \& practice (Wayne State University, Detroit, 1990), p. 11.

43. H Nowotny, "Introduction: the quest for innovation and cultures of technology" in H Nowotny (ed.), Cultures of technology and the quest for innovation (Berghahn, eBook, 2006), pp. 3-5.

44. M Gibbons, C Limoges, HNowotny, S Schwartzman, P Scott and MTrow, The new production of knowledge: the dynamics of science and research in contemporary societies (Sage Publications, Thousand Oaks, London and New Delhi, 1994).

45. M Gibbons, C Limoges, H Nowotny, S Schwartzman, P. Scott and M Trow, The new production of knowledge: the dynamics of science and research in contemporary societies ([First edition, 1994], Sage, London, Reprint, 2004), p. 5.

46. Ibid., pp. 17-45. 
Science, summarised the state of affairs in American universities, where stagnation had apparently set in. He argued:

Change will not come easily... The rigid departmental structure has become outmoded. Many of the best opportunities for significant scholarship lie in multidisciplinary areas... (S)ociety has problems; universities have departments. ${ }^{47}$

In some respects the focus of the humanities has increasingly shifted in the direction of relevance. Similar to the focus of science, where there is a tendency to work on problems and not in disciplines, there is a tendency to cluster disciplines together and create new disciplines, as has been the case with Cultural Studies. ${ }^{48}$

\section{Water history at North-West University}

With the establishment in 2006 of the Research Niche for the Cultural Dynamics of Water (CuDyWat) at North-West University's Vaal campus, a concerted effort was made to provide history with a direct focus on water research. The group was formed in association with a variety of disciplines at the campus in which Public Management and Governance, Political Studies, Information Communications Technology (ICT) and Disaster Studies were major stakeholders. It was specifically a research project in the field of disaster studies, undertaken in conjunction with the African Centre for Disaster Studies at NWU's Potchefstroom campus, that the idea to begin focusing on 'water hotspot' research gained momentum. ${ }^{49}$

From the outset there was a preference for a transdisciplinary approach. The establishment in 2005 of a new journal, TD The Journal for Transdisciplinary Research in Southern Africa, bolstered this choice of approach. A number of international and national scholars of repute committed themselves to support the endeavour as members of the journal's advisory board. The niche area was considered to be an extension of plans in the faculty to promote transdisciplinarity.

The focus was also to expose students to the realities of everyday life and the way in which people interact with water. Instead of merely theorising from textbooks there was an acceptance of the fact that empirical research with a spontaneous accent on grounded theory ${ }^{50}$ would be part of the plans to promote innovative thinking.

A report on water-related problems of the Kgetleng Local Municipality in North West Province followed in 2006. ${ }^{51}$ The next year the focus shifted to the Upper Vaal River

47. PH Abelson, Editorial comment: "Evolution of higher education” in Science, 277(5327), 1997.08.08, p. 747 (my italics).

48. R Post, "Disciplinarity" in Critical Inquiry, 35(4), Summer 2009, p. 755.

49. CM Gouws, K Reyneke, JWN Tempelhoff, ES van Eeden, D van Niekerk and R Wuriga, "The December 2004-January 2005 floods in the Garden Route region of the Southern Cape", North-West University, Vanderbijlpark, May 2005).

50. C Robson, Real world research: a resource for social scientists ad practitioner-researchers ([1993], Second edition, Blackwell Publishing, Malden, Oxford and Victoria, 2002), pp. 89, 190-192, 492-496.

51. M Ginster, CM Gouws, JWN Tempelhoff, $M$ van der Walt and $\mathrm{R}$ Wuriga, "Water in the Kgetlengrivier Local Municipality: The case of Koster" (North-West University, Vanderbijlpark, May 2006) 
catchment where the Barrage area, between the Vaal Dam and Rand Water's Barrage at Lindequesdrift formed part of a project to determine whether a strip of the river could be used to create an aquatic commons. Working with the non-governmental organisation Save the Vaal Environment (SAVE), members of the CuDyWat research group gained significant experience in research collaboration with civil society. ${ }^{52}$

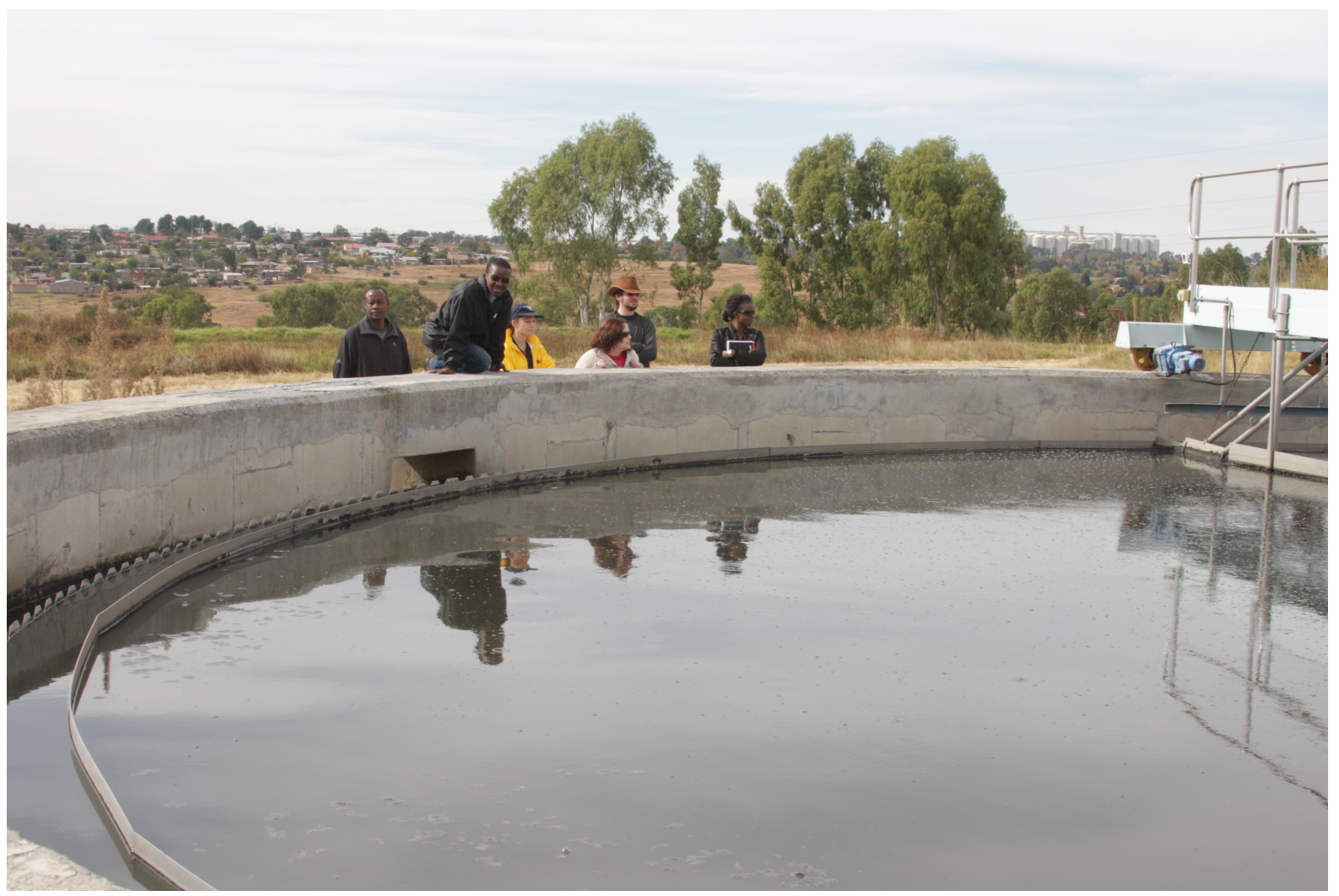

Figure 1 Members of the CuDyWat research team at the wastewater treatment works in Frankfort, Free State Province, May 2009 (Photograph JWN Tempelhoff)

North-West University's research management was supportive from the outset and provided limited seeding funds for CuDyWat's research. Then, in 2008, Fezile Dabi District Municipality contracted $\mathrm{CuDyW}$ at to undertake research on the Northern Free State town of Parys, which resorts under Ngwathe Local Municipality. There had been reports of considerable civil society discontent with local water service delivery. It was also the first time that the research group's focus fell on environmental health issues, particularly in respect of the Vaal River that bordered Parys. ${ }^{53}$

52. CM Gouws, C Gouws, R Mathipa, K Motumi, JWN Tempelhoff, and M Viljoen, "Perspectives on Emfuleni's aquatic commons: a qualitative study on the Vaal River Barrage", Report 3/2007, (NorthWest University, Vaal Triangle Campus, Released 2007.09.19).

53. JWN Tempelhoff, A van Zyl, G van Riet, C Gouws, H Jordaan, S Motloung, A Ludick, G van Greuning, J Hardy, A Venter, J Hardy, A Schlemmer, "An investigation into the environmental health of the Vaal River in the vicinity of Parys" (Report 01/2008, Research Niche Area for the Cultural Dynamics of Water, North-West University, Vaal Triangle Campus, Vanderbijlpark, 2008). 
NORTH-WEST UNIVERSITY

YUNIBESITI YA BOKONE-BOPHIRIMA

NOORDWES-UNIVERSITEIT

VAAL TRIANGLE CAMPUS
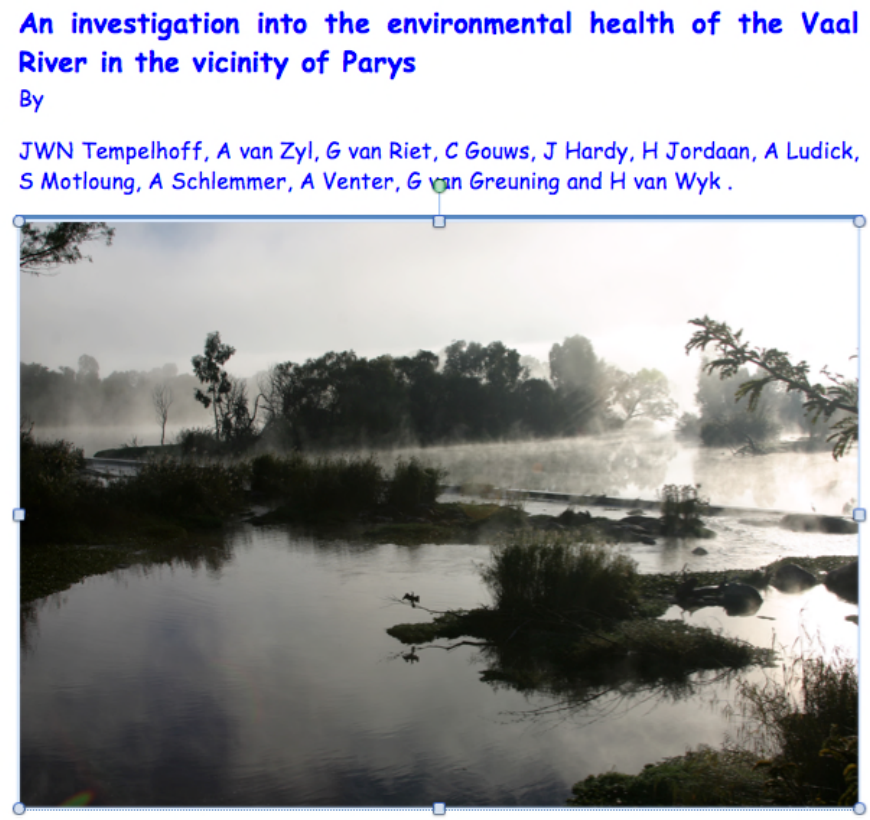

Research Niche Area for the Cultural Dynamics of Water

Vaal River Parys Project

Report No. 1/2008

NWU, Vaal Triangle Campus

Vanderbijlpark

(Final report)

30 November 2008

\section{Figure 2 Ngwathe report 2008}

The report was used by officials in the environmental health division of Fezile Dabi to start monitoring strategies aimed at improving water service delivery in Ngwathe Local Municipality. It also provided the district municipality with grounds to claim support from the department of water affairs in terms of funding and human resources. This support helped to address some of the problems of deteriorating water infrastructure and a shortage of skilled human resources. Two members of the research team also produced a report, published in article form, on dealing with disaster risk reduction and the environmental health of the Vaal River at Parys. ${ }^{54}$ Another spin-off of the project was that work began on a

54. G van Riet and JWN Tempelhoff, "Slow-onset disaster and sustainable livelihoods: the Vaal River in the vicinity of Parys" in TD The Journal for Transdisciplinary Research in Southern Africa, 5(1), July 2009, pp. 29-49. 
$\mathrm{PhD}$ thesis on the cultural history of the Vaal River and the Vredefort Dome, focusing on the impact of the quality of the river's water on this listed UNESCO World Heritage site. ${ }^{55}$

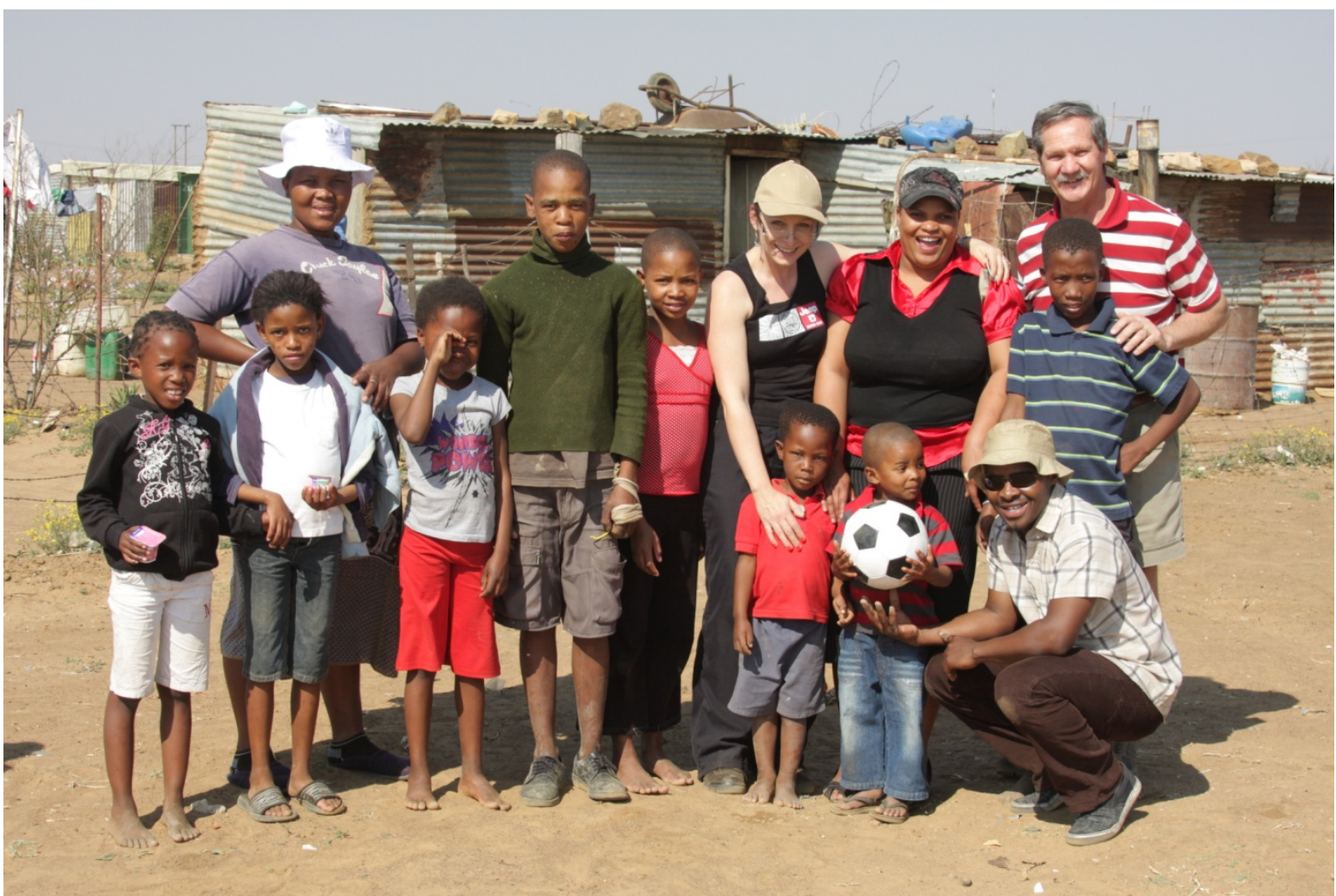

Figure 3 Researchers and members of the community in Sannieshof August 2009

In 2009, the first formal intake of postgraduate students and the collaboration with research and development specialists at SASOL, saw members of CuDyWat working for the first time on an institutional water theme. At the time the department of water affairs (DWA) experienced problems with the unlawful abstraction of water by irrigation farmers in the Eastern Free State from the Lesotho Highland Water Project's (LHWP) supplies flowing from Lesotho. The water was primarily intended for industrial and domestic consumption in the Gauteng Province. However, in view of the large quantities of water being abstracted the department had to contemplate beginning work on Phase 2 of the LHWP scheme before the original scheduled date of 2020, in order to secure sufficient supplies of water for Gauteng. ${ }^{56}$

The research was notable for its comprehensive stakeholder participation, and involved several officials of the department of water affairs; a consulting firm working in the irrigation sector for the state; local farmers; Agri SA's Free State division; as well as two post-doctoral students doing internships in $\mathrm{CuDyW}$ at in 2009. In addition to two field work excursions to

55. PhD project: C Gouws, "Vestiging langs die Vaalrivier in die Vredefortkoepel, 1840-2010: 'n kultuurhistorieseperspektief” (First draft scheduled for the end of 2011).

56. M Ginster, C Gouws, CM Gouws, H Mäki, R Mathipa, S Motloung, M Nyandoro, JWN Tempelhoff, "The problem of irrigation from Lesotho Highlands water in the Liebenbergsvlei River catchment, Eastern Free State Province"(Report 01/2009, Research Niche Area for the Cultural Dynamics of Water, North-West University, Vaal Triangle Campus, Vanderbijlpark, July 2009) (Final Report August 2009). 
the Eastern Free State, members of the research group also visited Lesotho where they could observe for themselves the Katse Dam and parts of the African Mountain Kingdom where valuable water intended for Gauteng Province, was being stored. The impact of the report was not immediately evident. However, information that reached the members of the research team indicated that many of the recommendations made in the report were either already in place or were in the process of being implemented. This was evident from:

- the farming community's willingness to cooperate with DWA officials on this particular problem that affected all parties;

- a collective move made by the stakeholders in the direction of establishing a water users' association (WUA); and

- personal disclosures made by DWA officials to members of the research group about how 'useful' the report had proved to be.

Perhaps the most important feature of this specific report was that it provided insight into how individual role players and local stakeholder sectors perceived the issue of water use. Officials and irrigation farmers had different perspectives. Some irrigation farmers who did not comply with the requirements of the department seemed eager to justify their actions in moral terms; there were even threats of court cases. Officials, on the other hand, were made aware of farmers' frustrations. For example, there were countless personal disclosures on how water users were sent from pillar to post when they wanted to register their details with the department. Management problems also surfaced as perennial issues that were interwoven threads in the tapestry of the history of water on the banks of the Liebenbergsvlei. Despite advice by consultants, officials had not performed their management and administrative tasks efficiently. In turn, motivated by sheer frustration with the lack of proper local water governance, many water users had resorted to unlawful water abstraction activities.

The second report in 2009 was a case study on how civil society took over the operations of a local authority in the North West Province town of Sannieshof, where the Tswaing Local Municipality were guilty of gross neglect as far as water service delivery was concerned. In this report it was argued that as an outcome of the years of struggle against apartheid, the post-1994 ruling party and its leadership, along with the others who had framed the 1996 Constitution of South Africa, had paid insufficient attention to the significance of a basic human right to happiness. 'Ordinary people' had simply been overlooked in the process of local development and their right to basic services such as a reasonable supply of water was tantamount to 'being forgotten' by the politicians. ${ }^{57}$ To put it another way, officials and politicians at the helm of the 'new' South Africa's local government structures did not appear to care for the basic happiness of previously disadvantaged people - although they relied on their votes at elections.

57. C Gouws, MI Moeketsi, S Motloung, JWN Tempelhoff, G van Greuning, "I hate it when people don't like me': SIBU and the crisis of water service delivery in Sannieshof, North West Province" (Report 02/2009, Research Niche Area for the Cultural Dynamics of Water, North-West University, Vaal Triangle Campus, Vanderbijlpark, October-November 2009). 


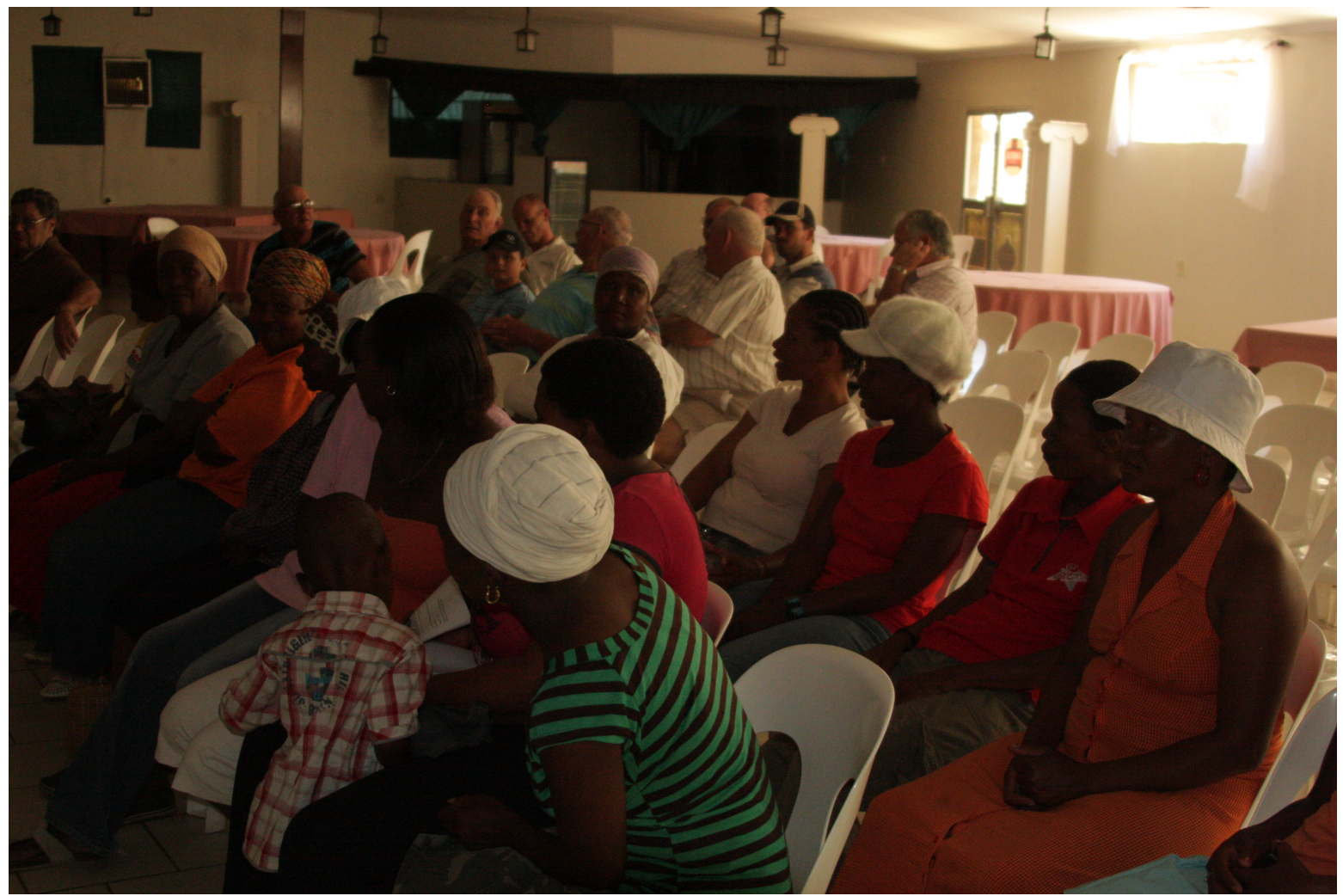

Figure 4 Stakeholders participating in deliberations over research in Sannieshof 2009

At the time of the report's release, there were rumblings in the politics of the ruling African National Congress (ANC) in North West Province. President Jacob Zuma had just begun his first term in office in May 2009. By October, as the CuDyWat research report was finalised, the ANC started taking steps to 'clean up' some of its problems in the province and some officials in the local municipality were subsequently replaced. The report encouraged the ruling ANC and the opposition party (the Democratic Alliance) in the North West provincial government to begin deliberations on addressing the problems of Sannieshof and other towns where similar problems prevailed. More importantly, the report provided local residents with a contemporary historical chronicle of their local struggle to secure essential basic services.

In 2010 the research group's first project focused on the Free State town of Harrismith, where the Maluti a Phofung Local Municipality had experienced serious service delivery protests in 2004 that literally became the benchmark for countrywide protest activities. The Harrismith protest was directly as a result of the municipality's failure to provide sufficient water services to local residents. The significance of the research project was that 2010 was the year of South Africa's hosting the FIFA Football World Cup. Indications were that with the world's eyes on South Africa service delivery protests might be resumed in Harrismith. A foretaste of what could be expected emerged in October 2009 when for the second time since 2004, local residents blocked the N3-highway between Gauteng and the coastal metropolis of Durban in KwaZulu-Natal. There was an underlying threat that the Harrismith local authority might well have to brace itself for N3 protest, version 3. The CuDyWat research team hoped to determine how the anticipated protest might be circumvented. There were concerns that service delivery activism would create a bad impression of South Africa when 
thousands of overseas visitors were in the country. The research proved to be of significant value in that it highlighted some of the local frustrations. It also pointed to what had been done since 2004 to improve local water services. ${ }^{58}$ In broad terms the report showed that the urban-rural divide and water service delivery in the Eastern Free State remained a problematic dichotomy; to address this would require special skills on the part of officials and politicians. The research fieldwork and report also provided valuable data for a $\mathrm{CuDyWat}$ student who was working towards a master's degree..$^{59}$

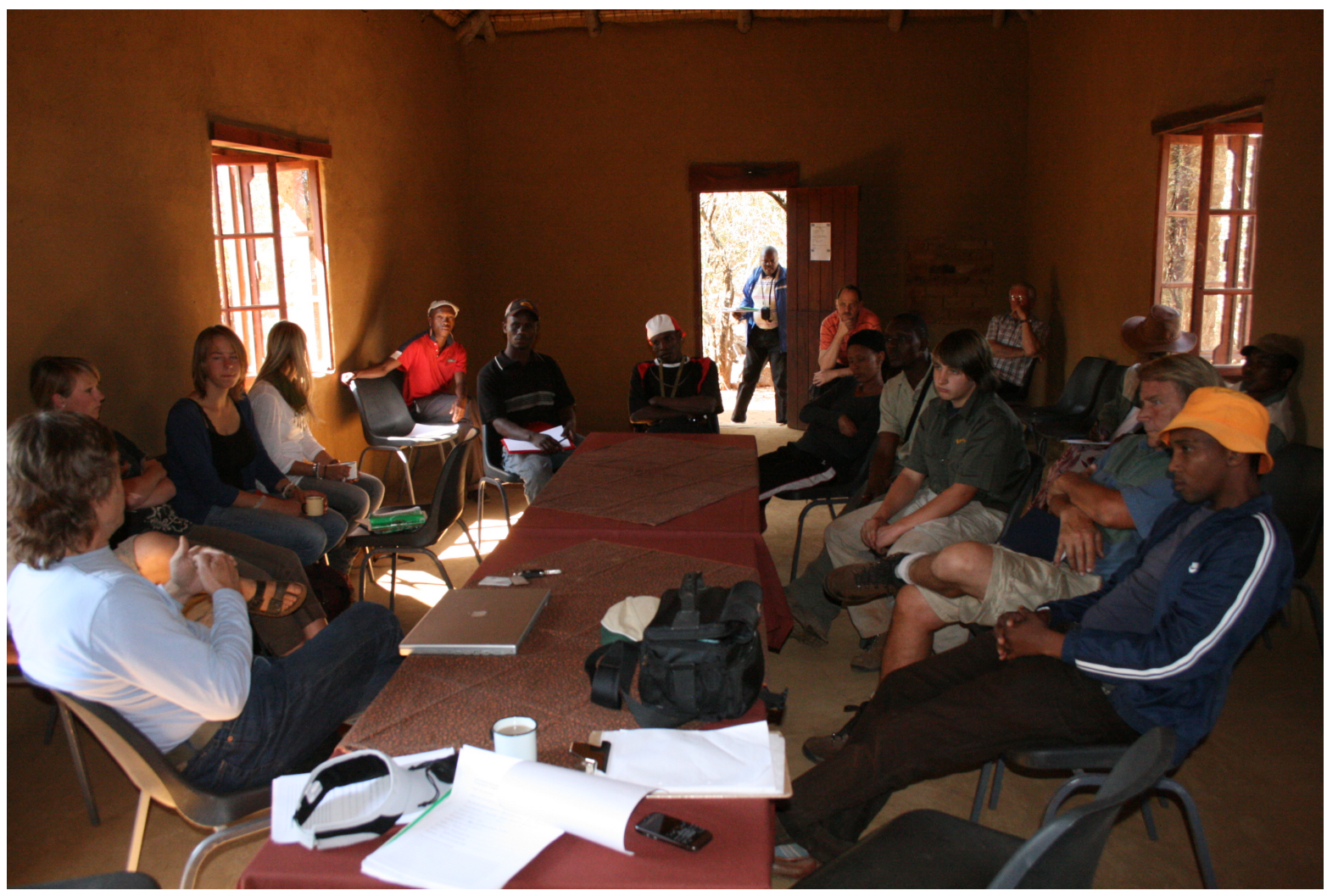

Figure 5 Stakeholders and researchers sharing views. Marico 2010

In recent years, civil society has tended to take a strong stand against mining activities in South Africa. Their views have been largely shaped by the crisis caused by toxic and even radioactive acid mine drainage decanting from deserted mining operations on the goldfields of Gauteng. It came to the attention of members of CuDyWat that residents in the Groot Marico River catchment of North West Province were up in arms about nickel prospecting in their area. A project was then launched, in conjunction with the Federation for a Sustainable Environment (FSA), to document the perceptions of local residents and their views on how they thought plans to mine for nickel in their area would affect their way of life in the region. The report, written by research leaders and students of $\mathrm{CuDyWat}$, was co-authored with the help of local residents; several German students who were doing community service in the

58 . C.M. Gouws, B. Mbambo, I. Moeketsi, M. Morotolo, S. Motloung, J.W.N. Tempelhoff, "What about the votes? Water, sanitation and civil disorientation: the case of Maluti-a-Phofung local municipality (Harrismith)", (Research report by the Research Group for the Cultural Dynamics of Water (CuDyWat), 1/2010).

59. S Motloung, "The influence of political culture and socialization on integrated water resource management (IWRM): the case of the Thabo Mofutsanyane District Municipality", (MA, in Political Science, North-West University (Vaal), 2011. Study leader: Dr CM Gouws). 
Marico region in 2010; a DWA official; and a postgraduate student registered at Monash University in Gauteng. The major impact of the report was that it provided local residents who had been active in their opposition to nickel mine prospecting, with a working document that was used to convince government officials to halt what was considered to be irresponsible and dangerous nickel prospecting in a sensitive riverine area of North West Province. In a secondary context the report made the local community aware of the need for residents to cooperate across the racial divide and start communicating on issues that were of vital importance to all the people of the area. ${ }^{60}$

In 2011, two funded projects were launched. In the first of these, in which CuDyWat is collaborating closely with Mvula Trust, a non-governmental organisation for water and sanitation in South Africa's rural areas, the focus is on civil society participation in water forums functioning in sub-catchments of the Upper Vaal River. ${ }^{61}$ The objective is to work on strategies to make the forums more representative of civil society and also to create opportunities for the more effective integration of civil society in the evolution of catchment management agencies (CMAs), the regional governing authorities. The second project, for Fezile Dabi District Municipality, is to look at the issue of the environmental health of water in the local municipalities of Moqhaka and Mafube. These local authorities are currently faced with serious problems in the management and development of their existing water and sanitation infrastructure. Simultaneously there is a need to work on management strategies to integrate water quality monitoring in Fezile Dabi District and neighbouring districts, located in the provinces of Gauteng, North West and Mpumalanga. ${ }^{62}$ The focus on transboundary collaboration on water quality monitoring has already been identified as a mini-dissertation project and may possibly be extended to a $\mathrm{PhD}$ thesis. Also emanating from this transboundary collaboration research project is a study on occupational health and safety, in respect of water problems in prisons of the Northern Free State. Seen from a research perspective, the project is interesting; it has a bearing on silenced people - incarcerated people, serving sentences - who do not have a voice to speak about the conditions in some of the prisons in the Northern Free State Province. ${ }^{63}$

At the time of going to print $\mathrm{CuDyWat}$ is also collaborating in a comprehensive research project, funded by the National Research Foundation (NRF), known as the Akili Project.

60. E Bertram, K Breytenbach, A Faul, C Gouws, M Hoffmann, J Khoadi, S Motloung, M Liefferink, S Pretorius, B Sheer, M Sturm, JWN Tempelhoff, AS van Zyl, T Wacker and S Weaver, "Rediscovering water roots: the consequences of nickel mine prospecting in the Groot Marico River region, South Africa”, (CuDyWat Report 2/2010, NWU, Vaal, Vanderbijlpark 2010).

61. V Munnik, V Molose, , B Moore, J Tempelhoff, I Gouws, I, S Motloung, Z Sibiya, A van Zyl, P Malapela, B Buang, B Mbambo, J Khoadi, L Mhlambi, M Morotolo, R Mazibuko, M Mlambo, I Moeketsi, N Qamakwane, N Kumalo and A Tsotetsi, Draft Consolidated Report: The Potential of Civil Society Organisations in monitoring and improving water quality (Draft version for use at the Citizens Assembly 26 October 2011, October 2011).

62. A preliminary outline of the project was discussed with peers. See J Tempelhoff, AS van Zyl and BJJ Lombard, "Environmental health and transboundary water quality in South Africa's Vaal River: towards assessment hermeneutics", Paper presented at the td-net Network for Transdisciplinary Research conference, "Evaluation of inter- and transdisciplinary research: experiences and reflections on best practice", Berne Switzerland, 14-16 September 2011.

63. PhD Project: MJJ Khoadi, "The management of occupational health and safety in water in Northern Free State prisons" (Scheduled for completion 2013-4). 
This involves water researchers from a number of South African universities and transdisciplinary theorists at the University of Stellenbosch's Institute for Advanced Studies (STIAS), all of who are working on aspects of water research.

\section{CuDyWat's research focus}

In spatial contexts, the activities of the research niche have for the most part been confined to the Upper Vaal River catchment. However, as a result of the relevance of some 'hotspot' issues, the catchments of the Crocodile River and the Harts River, specifically as they flow through North West Province, have also been under investigation. There have also been projects focusing on climate change and disaster studies in the arid Northern Cape and the Eden District of the Western Cape. These areas have served as research benchmarks for the potential historical interpretation of climate change trends. ${ }^{64}$

The role of history in the research projects is to provide a background to the study of contemporary issues. South Africa's transition to a multiracial democracy in 1994 saw the deconstruction of the historical consciousness (and popular memory) of a society that for more than 300 years tended to be Euro-centric in its interpretation of the country's past. The problem of this 'conventional' approach to historical studies became evident to the author in his research on the history of irrigation in South Africa. For a start, while it was clear that South Africa has a notable and colourful history of modern irrigation, hardly any research has been undertaken on pre-colonial irrigation. This is presumably the result of superficial heritage memory overlays of modern technology in South Africa, especially since the nineteenth century. In the process of introducing new technologies from the British colonies, as well as those from the United States, indigenous irrigation was literally overlooked and ignored. ${ }^{65}$ It is clear that a different approach to studying the past is required. By delving into aspects of pre-colonial water history it was possible to reach a better understanding of how humankind managed to survive in a water-stressed region on the subcontinent of Africa. ${ }^{66}$

On the formal educational level, the discipline of historical studies has declined in popularity because the vision of the country since the mid-1990s has been focused firmly on the future and the prospects for development. A major problem that emanated from this state of affairs was that especially in the water sector, as a result of water professionals going into early retirement, or becoming consultants, a great deal of institutional memory was lost. Therefore $\mathrm{CuDyWat}$ projects aim to locate lacunae of historical memory that can inform stakeholders on how conditions have evolved up to the present and the ways in which this is linked to the need for a future perspective.

64. D van Niekerk, J Tempelhoff, W Faling, L Thompson, D Jordaan, C Coetzee and Y Maartens, "The effects of climate change in two flood laden and drought stricken areas in South Africa: Responses to climate change - past, present and future" (African Centre for Disaster Studies, in conjunction with CuDyWat and George Museum, NWU, Potchefstroom, 2009).

65. JWN Tempelhoff, "Historical perspectives on pre-colonial irrigation in Southern Africa" in African Historical Review, 40(1), July 2008, pp. 121-160.

66. JWN Tempelhoff, "The commodification of water in the arid and semi-arid parts of South Africa: a preliminary historical exploration" in Historia, 50(1), May 2005, pp. 123-146.

Td, 7(1), Julie 2011, pp. 316- 336. 
Participant postgraduate students in CuDyWat's projects have come from a variety of disciplines. It was required of students to have the equivalent of an Honours degree with a good pass, before they were granted access to further studies. Within the group, the focus is then on solving a water-related problem, making use of the all the academic skills available in the research team. Students conduct research and do their writing in collaboration with participating stakeholders who have practical experience and knowledge of local conditions and the nature of the problem.

A concerted effort is made in the activities of the research group to promote an awareness of history as being valuable to transdisciplinary research. Some leading theorists in the field tend to underline the importance of history. They are aware of the contribution historical studies can make in terms of its particular approach to sources, ${ }^{67}$ and the valuable insights generated from historical perspectives. ${ }^{68}$ It appears that specifically in the fields of heuristics and hermeneutics, historical studies can play a vitally important role in transdisciplinary research.

Each of CuDyWat's projects contributes to an electronic archive, which now comprises a wide variety of multimedia source materials such as digital photographs; audio recordings of interviews; and secondary electronically printed source materials. All the material is at the collective disposal of members of the research team. The enthusiasm with which the concept of an archive is received amongst participants is testimony to the growing popularity in a variety of disciplines for the use of the archive as a conceptual element and component in research. ${ }^{69}$ The information also includes digitally processed handwritten and typed notes of interviews with all respondents. These are important primary sources that participants in the project interpret in the process of reporting on their findings.

Thus far only still photographs have been used, but the chances are that in future snippets of audio-visual video recordings will also be used for absorption into electronic texts. In addition, illustrative material is important. It provides comprehensive and fertile interpretative platforms. Some qualitative research groups in the field make use of cartoons drawn by an artist at the time of group interview sessions. The drawings are then used for the creation of archetypes in the research discourse. ${ }^{70}$ There are a number of alternative strategies used for incorporating creative illustrative material in research of this kind.

As a rule the material collected in the heuristic process tends to be primarily of a qualitative nature. However, collaboration with natural scientists in 2008 saw the innovative

67. J Thompson Klein, "The dialogue sessions", in J Thompson Klein, W Grossenbacher-Mansuy, R Häberli, A Bill, RW Scholz and M Welti (eds), Transdisciplinarity: joint problem solving among science, technology, and society. An effective way for managing complexity (BirkhauserVerlag, Basel, 2001), p. 109.

68. On how history forms part an intrinsic part of transdisciplinarity, see B Nicolescu, Manifesto of transdisciplinarity (State University of New York, Albany, 2002).

69. H Paul, "Performing history: how historical scholarship is shaped by epistemic values" in History ETheory, 50(1), February 2011, p. 2.

70. Narrative Lab, "Understanding srakehlder engagement using narrative research". Presentations at the Water Research Commission 40 year celebration conference" 31 Agust - 1 Septembers, Emperor's Palace, Kempton Park. 
quantification of oral information in the analysis of data. ${ }^{71}$ There is considerable scope for a more comprehensive focus on processing qualitative data with computer-based software.

Students and researchers in $\mathrm{CuDyWat}$ have ready access to the data already gleaned in their current project as well as the archives of previous projects. Apart from using their own notes and pictures, they are also encouraged to make use of the material gathered by other participants in the research groups. Not all participants make use of the information. In cases where it has been used, the results have been satisfactory. As a rule, participants working from a disciplinary background in historical studies tend to perform the best in this field. Especially in respect of referencing systems - an approach intended to validate certain statements - the potential value of the data becomes evident.

The archives of the different projects were originally open and transparent for public access. In view of the confidential nature of some of the information collected, the understanding is now that the information can be viewed with prior permission and on the agreement to abide by certain regulations and limitations. Although there have not been any requests from outside, source materials can still be made available for external groups and/or individuals, providing that agreements are entered into to secure the dissemination of confidential or sensitive information.

Sources referred to in the text of individual and group projects, are subject to meticulous referencing. The convention of footnotes is used in all reports; this referencing system comfortably accommodates primary source material such as oral interviews. Originally, the names of respondents appeared in the footnotes. However, because of scientific ethical considerations and the need to respect the confidentiality and privacy of respondents, the names of respondents is now generally codified to protect their identity. Under some circumstances the names of respondents are still used but only if there is agreement that personal details of some respondents - especially community leaders and officials - may be used in the final reporting process. The latter arrangement is often aimed at shedding light on the thinking of important stakeholders in a research project.

In recent times there have been requests by external researchers to participate in CuDyWat's projects. As a general rule these are welcomed. There have even been requests for internships to participate in research. Up to the present the accommodation of participant researchers from outside has not always yielded the desired results. Some who visit South Africa for a limited period merely participate in fieldwork and then leave the country; often adequate lines of communication are not maintained thereafter.

The participation of civil society in the research projects has been largely successful. Initially there was some reticence; people tended to think that only 'academics' or 'real researchers' should contribute to writing and reporting. Strategies have been devised to ensure that the voice of civil society participants in the consolidation of text information is also registered. The process will be refined further in the future.

71. See H Jordaan, "Vaal River water quality project: Interim report to the research team Vaal River Environmental Health Project, Parys, June -August 2008" (Research Niche Area for the Cultural Dynamics of Water, North-West University, 2008) in archive. Also mentioned in JWN Tempelhoff, A van $\mathrm{Zyl}$, G van Riet, C Gouws, H Jordaan, S Motloung, A Ludick, G van Greuning, J Hardy, A Venter, J Hardy, A Schlemmer, "An investigation into the environmental health of the Vaal River in the vicinity of Parys" (Report 01/2008, Research Niche Area for the Cultural Dynamics of Water, North-West University, Vaal Triangle Campus, Vanderbijlpark, 2008).

Td, 7(1), Julie 2011, pp. 316- 336. 
At first, institutional stakeholders tended to be uncertain about the role they could play in the research process and some institutions introduced participants with a high political profile. This tended to be counterproductive, especially in research group discussions and debates. Then too, in some cases, institutional participation also lacked a sense of dedication and solidarity with the project.

An outstanding feature of transdisciplinary research is that it provides opportunities to add value and open up avenues for practical knowledge accumulation that are useful for research participants. In one project it was possible to take the members of the team on a weekend excursion to visit sites that had a bearing on the project. Not only did it create opportunities for socialisation, but it also facilitated an understanding of the broader dimensions of South Africa's water sector.

\section{Conclusion}

The transdisciplinary nature of CuDyWat's research activities has made it possible for postgraduate students and research leaders in the team to interact and exchange ideas on a variety of topics. For historians it has been an eye-opener to take note of the way in which educationists, health scientists, specialists in chemistry, engineers and management specialists, tend to think about matters. In many respects the agora is a knowledge space that also provides people at grassroots level with access to research. In turn, the 'ordinary person' contributes by making disclosures on how people outside the academe see certain issues. They also articulate, in collaboration with the researchers, how different stakeholders view problems. These problems usually tend to have a history. It is only once the historical background is understood that many of the wicked or benign issues can be solved in a sustainable manner.

For the discipline of history, a transdisciplinary approach to research can create a lifeline for the discipline in an era when the functional value of knowledge is a priority in what used to be the 'ivory towers' of academia. History, according to some managers of educational and research institutions, must serve the utilitarian function of addressing the need for understanding problems of the present - as in immediately. However, the days of history as an intellectual adventure for the reader in the sphere of the humanities are not necessarily numbered. There will always be a demand for good historical writing. But undeniably there is also a growing need for history in a rapidly developing world; a sense of social amnesia is proliferating in all parts of the world. This is largely the result of the vast amount of information that is constantly moving at an ever-increasing rate between consumers of information. This has contributed to the exponential growth of scientific knowledge, even in developing countries of the world. Many disciplines in the humanities and social sciences have become part of the increasing stream of knowledge in the realms of science and technology worldwide. History cannot afford to function in isolation in times such as these. 